\title{
Intraoperative immunomodulatory effects of sevoflurane versus total intravenous anesthesia with propofol in bariatric surgery (the OBESITA trial): study protocol for a randomized controlled pilot trial
}

Giselle Carvalho de Sousa ${ }^{1,2+}$, Fernanda Ferreira $\mathrm{Cruz}^{1+}$, Luciana Boavista Heil $^{1+}$, Carlos José Saboya Sobrinho ${ }^{3+}$, Felipe Saddy ${ }^{1,3}$, Frederico Paranhos Knibel ${ }^{3}$, Joana Barreto Pereira ${ }^{3}$, Marcus J. Schultz ${ }^{4,5}$, Paolo Pelosi ${ }^{6,7}$, Marcelo Gama de Abreu ${ }^{8}$, Pedro Leme Silva ${ }^{1}$ and Patricia Rieken Macedo Rocco ${ }^{1 *}$ (D)

\begin{abstract}
Background: Obesity is associated with a chronic systemic inflammatory process. Volatile or intravenous anesthetic agents may modulate immune function, and may do so differentially in obesity. However, no study has evaluated whether these potential immunomodulatory effects differ according to type of anesthesia in obese patients undergoing laparoscopic bariatric surgery.

Methods/design: The OBESITA trial is a prospective, nonblinded, single-center, randomized, controlled clinical pilot trial. The trial will include 48 patients with a body mass index $\geq 35 \mathrm{~kg} / \mathrm{m}^{2}$, scheduled for laparoscopic bariatric surgery using sleeve or a Roux-en-Y gastric bypass technique, who will be allocated 1:1 to undergo general inhalational anesthesia with sevoflurane or total intravenous anesthesia (TIVA) with propofol. The primary endpoint is the difference in plasma interleukin (IL)-6 levels when comparing the two anesthetic agents. Blood samples will be collected prior to anesthesia induction (baseline), immediately after anesthetic induction, and before endotracheal extubation. Levels of other proinflammatory and anti-inflammatory cytokines, neutrophil chemotaxis, macrophage differentiation, phagocytosis, and occurrence of intraoperative and postoperative complications will also be evaluated.
\end{abstract}

Discussion: To our knowledge, this is the first randomized clinical trial designed to compare the effects of two different anesthetics on immunomodulation in obese patients undergoing laparoscopic bariatric surgery. Our hypothesis is that anesthesia with sevoflurane will result in a weaker proinflammatory response compared to anesthesia with propofol, with lower circulating levels of IL- 6 and other proinflammatory mediators, and increased macrophage differentiation into the M2 phenotype in adipose tissue.

Trial registration: Registro Brasileiro de Ensaios Clínicos, RBR-77kfj5. Registered on 25 July 2018.

Keywords: Obesity, Inflammation, Cytokines, Interleukin 6, Lung injury, Propofol, Sevoflurane, Clinical trial

\footnotetext{
* Correspondence: prmrocco@gmail.com

${ }^{\dagger}$ Giselle Carvalho de Sousa, Fernanda Ferreira Cruz, Luciana Boavista Heil and Carlos José Saboya Sobrinho contributed equally as first authors.

1 Laboratory of Pulmonary Investigation, Carlos Chagas Filho Institute of

Biophysics, Federal University of Rio de Janeiro, Centro de Ciências da Saúde,

Avenida Carlos Chagas Filho, 373, Bloco G1-014, llha do Fundão, Rio de

Janeiro 21941-902, Brazil

Full list of author information is available at the end of the article
}

(c) The Author(s). 2019 Open Access This article is distributed under the terms of the Creative Commons Attribution 4.0 International License (http://creativecommons.org/licenses/by/4.0/), which permits unrestricted use, distribution, and reproduction in any medium, provided you give appropriate credit to the original author(s) and the source, provide a link to the Creative Commons license, and indicate if changes were made. The Creative Commons Public Domain Dedication waiver (http://creativecommons.org/publicdomain/zero/1.0/) applies to the data made available in this article, unless otherwise stated. 


\section{Background}

Obesity, a major public health issue, has long been recognized as a precursor of morbidity and premature mortality [1]. An increasing number of morbidly obese persons - defined by the World Health Organization as having a body mass index $(\mathrm{BMI}) \geq 40 \mathrm{~kg} / \mathrm{m}^{2}[1]$ - are undergoing surgical procedures.

Obesity is a metabolic disorder associated with chronic systemic inflammation, predominantly originating from visceral adipose tissue (VAT). Adipose tissue is composed of a number of immune cells [2, 3]; among these, macrophages have been shown to be the predominant cell population [4]. In obesity, adipocyte expansion increases the secretion of monocyte chemoattractants that recruit inflammatory monocytes expressing type $2+$ chemokine receptor (CCR2 + ) to the adipose tissue, where they differentiate into activated macrophages with the M1 phenotype [2]. M1 macrophages increase the production of proinflammatory cytokines such as tumor necrosis factor (TNF)- $\alpha$, interleukin (IL)-6, and IL-12, and the generation of reactive oxygen species, such as nitric oxide (NO), via the iNOS pathway (NOS2) [2, 3].

Caution is required when choosing anesthetic agents for administration in morbidly obese patients, since these drugs may influence immune function and the inflammatory process [5]. In this context, anesthetics may interact with the perioperative inflammatory response, affecting the release of cytokines [6], the expression of cytokine receptors [7], phagocytic or cytotoxic action [8], and the transcription or translation of protein mediators $[9,10]$, resulting in potential beneficial or deleterious effects. Sevoflurane, a volatile anesthetic, exerts a number of effects on innate immunity, mainly inhibiting neutrophil function, decreasing lymphocyte proliferation, suppressing the release of cytokines from peripheral blood mononuclear cells and circulating monocytes, and affecting the function of natural killer (NK) and dendritic cells $[8,11$, 12]. Propofol, an intravenous agent, has been shown to inhibit neutrophil chemotaxis [13], neutrophil oxidative response [14], macrophage phagocytosis [15], and bacterial clearance [16]. In a previous study, Heil et al. showed that in obese rats, anesthesia with propofol increased lung inflammation and airway resistance compared with dexmedetomidine and thiopental [17].

Previous studies compared sevoflurane with propofol on performance, effectiveness, recovery from anesthesia, and bispectral index (BIS) recordings (a marker of possible intraoperative awareness) [18, 19], but have not evaluated the immunomodulatory potential of these anesthetics in obese patients.

Overall, in centers with distinct expertise, the 30-day mortality rate in bariatric surgery is low (0.1-2\%) [20], as is the rate of major complications (3.6\% after gastric bypass and $2.2 \%$ after sleeve gastrectomy) [21]. However, apart from major and early complications, minor complications can still occur in the days following surgery, which may increase hospital length of stay. The inflammatory process is involved in the perioperative period, in which it impairs wound healing and increases the risk of infection. To date, no study has evaluated which anesthetic agent is associated with the least inflammation and fewest complications in obese patients undergoing surgery.

Therefore, we designed the OBESITA trial to assess the immunomodulatory effects of anesthetics and inform future sample size calculations for studies evaluating sevoflurane versus propofol in obese patients undergoing bariatric surgery. Our hypothesis is that anesthesia with sevoflurane will result in a weaker inflammatory response to surgery than anesthesia with propofol $[17,22]$.

\section{Methods \\ Study design}

The OBESITA study is a single-center, nonblinded, randomized controlled pilot trial with a 1:1 allocation ratio. A total of 48 patients scheduled to undergo laparoscopic bariatric surgery will be randomized to receive either inhalational anesthesia with sevoflurane or total intravenous anesthesia (TIVA) with propofol (see Consolidated Standards of Reporting Trials (CONSORT) diagram, Fig. 1) [23]. The protocol has been designed in accordance with the Standardized Protocol Items: Recommendations for Interventional Trials (SPIRIT) guidelines (Fig. 2) and the corresponding checklist (Additional file 1). Prior to surgery, patients will be approached by a member of the study team and informed written consent will be sought.

\section{Inclusion criteria}

Patients aged $18-59$ years with $\mathrm{BMI} \geq 35 \mathrm{~kg} / \mathrm{m}^{2}$, scheduled to undergo laparoscopic bariatric surgery under general anesthesia, will be eligible. Preoperative management of patients in both groups will be consistent with current surgical best practice and at the discretion of the operating surgeon. Patients at risk of postoperative pulmonary complications (PPCs) will be identified using the Respiratory Risk Assessment in Surgical Patients in Catalonia (ARISCAT) score [24], which consists of seven independent predictors: three patient-related and four surgery-related predictors (Table 1). An ARISCAT score $\geq 26$ denotes intermediate to high risk of PPCs. All medications used by patients will be queried during the preoperative interview with the anesthesiologist.

\section{Exclusion criteria}

The exclusion criteria are age $<18$ years or $>59$ years; insulin-dependent diabetes mellitus; anti-inflammatory and/or immunosuppressive therapies; a diagnosis of malignancy, chronic kidney disease (Kidney Disease 


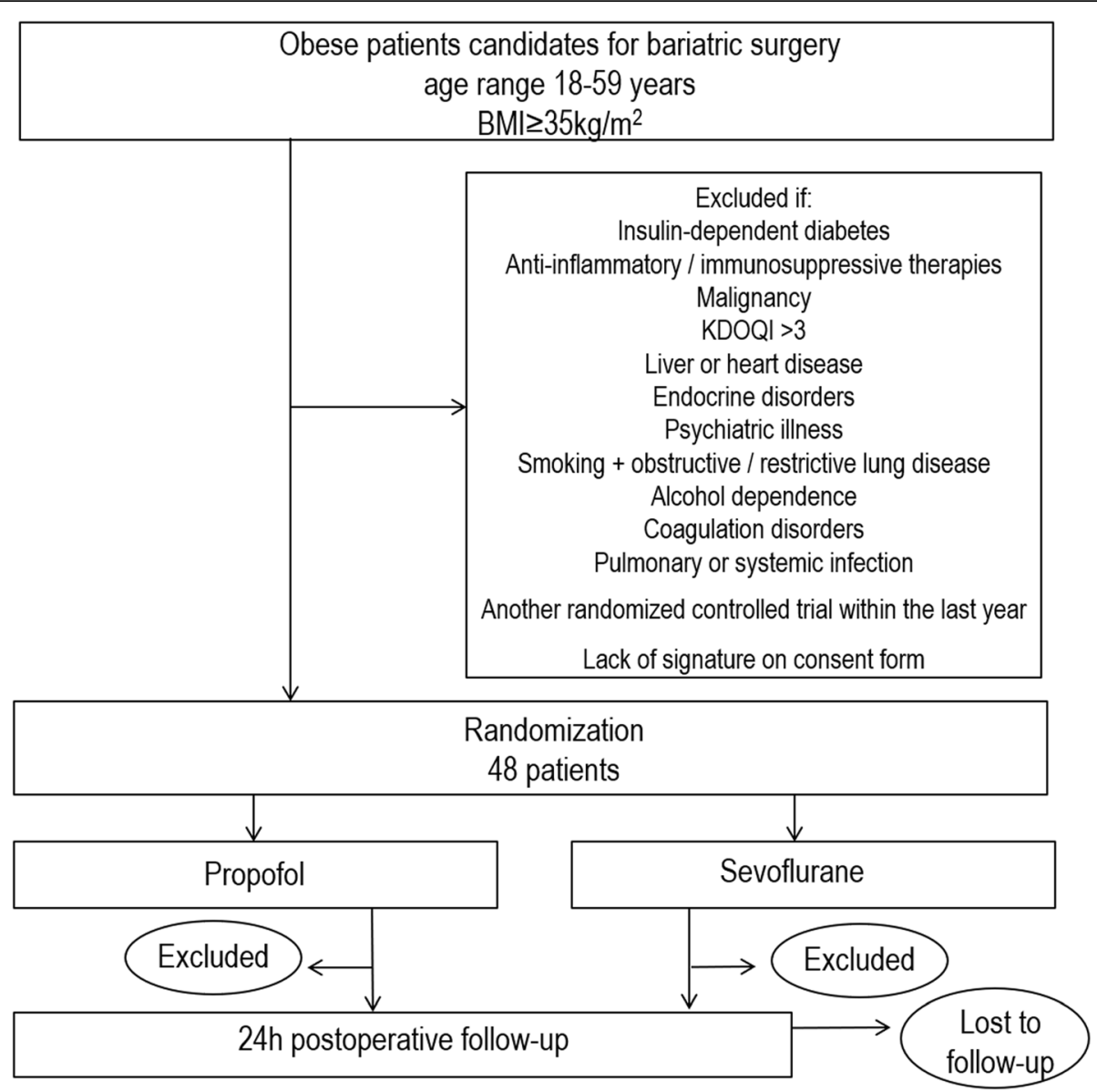

Fig. 1 Consolidated Standards of Reporting Trials (CONSORT) diagram. BMI, body mass index, KDOQI, Kidney Disease Outcomes Quality Initiative

\begin{tabular}{|c|c|c|c|c|c|}
\hline \multirow[b]{3}{*}{ Time point } & \multicolumn{5}{|c|}{ Study period } \\
\hline & \multirow{2}{*}{$\begin{array}{c}\text { Enrollment } \\
\mathrm{T}-1\end{array}$} & \multirow{2}{*}{$\begin{array}{c}\text { Allocation } \\
\text { TO }\end{array}$} & \multicolumn{2}{|c|}{$\begin{array}{c}\text { Post-allocation } \\
\text { (post-randomization) }\end{array}$} & \multirow{2}{*}{$\begin{array}{c}\text { Close-out } \\
\begin{array}{c}\text { Postoperative } \\
\text { day } 30\end{array}\end{array}$} \\
\hline & & & Day of surgery & $\begin{array}{l}\text { Postoperative } \\
\text { day } 1\end{array}$ & \\
\hline Enrollment & $x$ & & & & \\
\hline Eligibility screen & $x$ & & & & \\
\hline Informed consent & $x$ & & & & \\
\hline Allocation & & $x$ & & & \\
\hline \multicolumn{6}{|l|}{ Interventions } \\
\hline Propofol & & & $x$ & & \\
\hline Sevoflurane & & & $x$ & & \\
\hline \multicolumn{6}{|l|}{ Assessments } \\
\hline Baseline variables & $x$ & & & & \\
\hline $\begin{array}{l}\text { Analysis of } \\
\text { inflammation }\end{array}$ & & & $x$ & & \\
\hline $\begin{array}{l}\text { Clinical and surgical } \\
\text { complications }\end{array}$ & & & $x$ & $x$ & $x$ \\
\hline
\end{tabular}

Fig. 2 Standard Protocol Items: Recommendations for Interventional Trials (SPIRIT) diagram. Schedule of enrollment, interventions, and assessments for the OBESITA trial 
Table 1 Independent predictors of risk for PPCs identified in the logistic regression model (ARISCAT score)

\begin{tabular}{|c|c|c|c|}
\hline & $\begin{array}{l}\text { Multivariate analysis } \\
\text { OR }(95 \% \mathrm{Cl}) \\
n=1.624^{*}\end{array}$ & $\beta$ & Risk score $^{a}$ \\
\hline \multicolumn{4}{|l|}{ Age, years } \\
\hline$\leq 50$ & 1 & & \\
\hline $51-80$ & $1.4(0.6-3.3)$ & 0.331 & 3 \\
\hline$>80$ & $5.1(1.9-13.3)$ & 1.619 & 16 \\
\hline \multicolumn{4}{|l|}{ Preoperative $\mathrm{SpO}_{2}, \%$} \\
\hline$\geq 96$ & 1 & & \\
\hline $91-95$ & $2.2(1.2-4.2)$ & 0.802 & 8 \\
\hline$\leq 90$ & $10.7(4.1-28.1)$ & 2.375 & 24 \\
\hline RTI in preceding month & $5.5(2.6-11.5)$ & 1.698 & 17 \\
\hline Preoperative anemia $(\mathrm{Hb} \leq 10 \mathrm{~g} / \mathrm{dL}$ ) & $3.0(1.4-6.5)$ & 1.105 & 11 \\
\hline \multicolumn{4}{|l|}{ Surgical incision } \\
\hline Peripheral & 1 & & \\
\hline Upper abdomen & $4.4(2.3-8.5)$ & 1.480 & 15 \\
\hline Intrathoracic & $11.4(4.9-26.0)$ & 2.431 & 24 \\
\hline \multicolumn{4}{|l|}{ Duration of surgery, hours } \\
\hline$\leq 2$ & 1 & & \\
\hline$>2-3$ & $4.9(2.4-10.1)$ & 1.593 & 16 \\
\hline$>3$ & $9.7(4.7-19.9)$ & 2.268 & 23 \\
\hline Emergency procedure & $2.2(1.0-4.5)$ & 0.768 & 8 \\
\hline
\end{tabular}

Three patients were excluded because of a missing value for some variables. Logistic regression model constructed with the development subsample, $c$-index $=$ 0.90; Hosmer-Lemeshow chi-square test $=7.862 ; P=0.447$

$\mathrm{Cl}$ confidence interval, $\mathrm{Hb}$ hemoglobin, $\mathrm{OR}$ odds ratio, $P P C$ postoperative pulmonary complications, $R T /$ respiratory tract infection, $\mathrm{SpO} 2$ oxyhemoglobin saturation by pulse oximetry (breathing room air in the supine position)

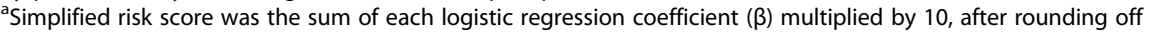

Outcomes Quality Initiative (KDOQI) score $>3$ ), liver disease (total serum bilirubin $<3 \mathrm{~g} / \mathrm{dL}$ and total bilirubin $>5 \mathrm{mg} / \mathrm{dL}$ ), or heart disease (New York Heart Association (NYHA) class III/IV); obesity caused by endocrine disorders; psychiatric illness that might interfere with capacity for formal consent and compliance; persistent smoking associated with significant obstructive lung disease (forced vital capacity (FVC) or forced expiratory volume in one second $\left(\mathrm{FEV}_{1}\right)<$ $50 \%$ of predicted value) or restrictive lung disease (pre-bronchodilator $\mathrm{FVC}<80 \%$ of predicted value and $\mathrm{FEV}_{1} / \mathrm{FVC} \geq 0.7$ ) [25]; alcohol dependence; pre-existing coagulation disorders; evident pulmonary or systemic infection (clinical diagnosis or any one of the following: C-reactive protein $>5 \mathrm{mg} / \mathrm{L}$, leukocytosis with $>10,000$ white blood cells (WBCs), or body temperature $>37^{\circ} \mathrm{C}$ ); autoimmune diseases; and participation in another randomized controlled trial within the preceding year.

\section{Intervention}

Patients will be randomly assigned to receive general anesthesia with either sevoflurane alone or propofol alone. Anesthesia will be maintained with approximately 1 minimum alveolar concentration (MAC) in the sevoflurane group; in the propofol group, anesthesia will be maintained with a continuous infusion of $2-4 \mu \mathrm{g} / \mathrm{mL}$ in a target- controlled infusion pump programmed with the Marsh pharmacokinetic model, using adjusted body weight, aiming to maintain a suitable level of hypnosis (bispectral index (BIS) 40-60) [26].

\section{Minimization of bias}

Patients will be randomized using a computer-generated random number table, with an allocation ratio of 1:1. The allocation sequence will be implemented by a telephone call at the time of surgery. An investigator will collect data, and blood and adipose tissue samples will be coded so that the investigator evaluating the laboratory outcomes remains blinded to group allocation.

\section{Standard care}

Patients assigned to both groups will receive intravenous fluids at a volume of $10-15 \mathrm{~mL} / \mathrm{kg}$ total body weight (TBW) if possible [27, 28]. According to patient randomization, anesthesia in the TIVA with propofol group will be induced using propofol (1.5-2 
$\mathrm{mg} / \mathrm{kg}$ ideal body weight (calculated as height in $\mathrm{cm}$ - $\mathrm{x}$, where $\mathrm{x}=100$ in adult men and 105 in adult women)) [29], whereas in the sevoflurane group, anesthesia will be induced using midazolam (0.05$0.15 \mathrm{mg} / \mathrm{kg} \mathrm{TBW)}$ [29]. All patients will then receive alfentanil $(15-20 \mu \mathrm{g} / \mathrm{kg}$ lean body weight (LBW), defined in men as $1.1 \times$ (weight) $-128 \times$ (weight $/$ height) ${ }^{2}$ and in women as $1.07 \times$ (weight $)-148 \times(\text { weight } / \text { height })^{2}$ [30] and rocuronium $(1.2 \mathrm{mg} / \mathrm{kg} \mathrm{IBW}))$ [31]. Patients will receive a continuous infusion of remifentanil $(0.1-0.4 \mu \mathrm{g} / \mathrm{kg} / \mathrm{min}$ LBW) after induction of anesthesia and during surgery [31]. All patients will undergo neuromuscular monitoring with quantitative devices [32]. Patients will be extubated using sugammadex $2 \mathrm{mg} / \mathrm{kg} \mathrm{IBW}$ if the train of four (TOF) is $\geq 2$ responses or sugammadex $4 \mathrm{mg} / \mathrm{kg} \mathrm{IBW}$ if $\mathrm{TOF}=0$ and the post-tetanic count (PTC) is $\geq 1$ (33) [33].

After closure of the surgical incision, morphine $(0.08$ $\mathrm{mg} / \mathrm{kg}$ IBW) will be administered intravenously [29]. Postoperative analgesia will consist of dipyrone (metamizole) $1 \mathrm{~g}$ every $6 \mathrm{~h}$, ketoprofen $100 \mathrm{mg}$ every $12 \mathrm{~h}$ or parecoxib $40 \mathrm{mg}$ every $12 \mathrm{~h}$, and tramadol $50-100 \mathrm{mg}$ every $8 \mathrm{~h}$ or as rescue analgesia. Ondansetron ( $4 \mathrm{mg}$ every $8 \mathrm{~h}$ ) will be administered as prophylaxis for nausea and vomiting.

\section{Samples}

Blood $(15 \mathrm{~mL})$ will be collected in heparinized tubes prior to induction of anesthesia (baseline), immediately after anesthetic induction (T1), and before extubation (T2).

Two small fragments of subcutaneous adipose tissue and visceral adipose tissue will also be sampled. Each fragment will measure $2 \times 2 \times 2 \mathrm{~cm}$ after excess blood vessels and connective tissue have been removed with the aid of a scalpel, and will be obtained from surgical specimens that would be discarded immediately following gastroplasty.

\section{Mechanical ventilation}

Patients from both groups will be mechanically ventilated in pressure-controlled mode, with a tidal volume $\left(\mathrm{V}_{\mathrm{T}}\right)$ of 5-7 ml/kg IBW, respiratory rate (RR) adjusted to maintain arterial partial pressure of carbon dioxide $\left(\mathrm{PaCO}_{2}\right)$ between 36 and $44 \mathrm{mmHg}$, and a positive end-expiratory pressure (PEEP) of $5 \mathrm{cmH}_{2} \mathrm{O}$ [34]. The inspired fraction of oxygen $\left(\mathrm{FiO}_{2}\right)$ will be adjusted to maintain oxygen saturation of hemoglobin $\left(\mathrm{SaO}_{2}\right)>95 \%(0.4-0.5)$.

\section{Rescue strategies for intraoperative hypoxemia}

Based on the protocol used in the PROBESE trial [35], if oxygen saturation falls to $92 \%$ or below, factors such as increased airway resistance, presence of intrinsic PEEP, hemodynamic instability, and ventilator malfunction should be excluded.

Initially, $\mathrm{FiO}_{2}$ should be raised gradually. Elevation of PEEP is restricted to more severe cases, when hypoxemia persists with $\mathrm{FiO}_{2}=1.0$. In this case, PEEP is gradually increased to $7 \mathrm{cmH}_{2} \mathrm{O}$. Alveolar recruitment maneuvers should be performed if $\mathrm{SaO}_{2}$ remains $\leq 92 \%$ [35].

Anesthesiologists may deviate from the ventilation protocol at any time if concerns about patient safety arise. PEEP may be modified at the anesthesiologist's discretion.

\section{Measurements}

The following ventilatory parameters will be measured at three time points - after anesthetic induction (approximately $10 \mathrm{~min}$ ), after induction of pneumoperitoneum (approximately $20 \mathrm{~min}$ ), and at the end of surgery: minute ventilation, $R R, V_{T}$, peak and plateau pressures, PEEP, static and dynamic compliance, $\mathrm{FiO}_{2}$, and $\mathrm{SaO}_{2}$.

Arterial blood gases and hemoglobin level will be measured immediately after induction of anesthesia and before extubation.

Heart rate (HR) and noninvasive mean blood pressure (NIBP) will be measured throughout the procedure. The duration of surgery, the time before and after pneumoperitoneum, intra-abdominal pressure throughout the procedure, and the volume insufflated to achieve pneumoperitoneum will also be recorded.

\section{Postoperative data}

The following clinical data will be evaluated within $24 \mathrm{~h}$ of surgery: vital signs (HR, NIBP, RR, and axillary temperature (AT)), complete physical examination, presence of organ dysfunction, visual analogue scale (VAS) score for pain, and postoperative complications (pulmonary infection, systemic inflammatory response syndrome, sepsis, septic shock, extrapulmonary infection, coma, acute myocardial infarction, acute renal failure, disseminated intravascular coagulation (DIC), gastrointestinal failure (GIF), and acute liver failure).

\section{In vitro assays}

\section{Blood samples}

Blood samples will be collected from all patients at baseline, T1, and T2. Heparinized tubes will be immediately centrifuged at $1500 \times g$ for $5 \mathrm{~min}$ at $4{ }^{\circ} \mathrm{C}$ for separation of plasma and cells. These samples will be centrifuged within $6 \mathrm{~h}$ of collection. Plasma will be stored at $-80^{\circ} \mathrm{C}$ until the time of analysis. The cell pellet will be used for monocyte and neutrophil isolation and evaluation, while plasma will be used later (after perioperative monitoring) for quantification of $\mathrm{C}$-reactive protein (CRP), procalcitonin (PCT), IL-6, IL-10, and TNF- $\alpha$ levels.

\section{Adipose tissue fragments}

Adipose tissue fragments will be subjected to enzymatic digestion with $1 \mathrm{mg} / \mathrm{mL}$ collagenase IA (Sigma Chemical Co., St. Louis, USA) for $30 \mathrm{~min}$ at $37^{\circ} \mathrm{C}$. The remaining tissue will be filtered through a 100-mm pore nylon mesh, and 
proteolysis will be interrupted with high-glucose Dulbecco's modified Eagle's medium (DMEM, Gibco, Invitrogen, NY, USA) with 20\% fetal bovine serum (FBS) (Hyclone Laboratories Inc., UT, USA) and 1\% penicillin and streptomycin solution (Gibco, Invitrogen, NY, USA). The cells will be centrifuged and washed twice with $0.01 \mathrm{mM}$ phosphate-buffered saline (PBS), and will then be prepared for magnetic selection.

Total leukocytes obtained from blood and adipose tissue will be analyzed by diluting the samples in Türk's liquid (1:10) and counting cells in a Neubauer chamber under a light microscope (BX51, Olympus, Tokyo, Japan). Slides will be stained for the differential cell count using the May- Grünwald-Giemsa method and visualized with an oil- immersion objective under the same microscope. Monocytes and neutrophils will be isolated by the magnetic sorting technique (Invitrogen, CA, USA) through incubation with biotin-associated anti-CD11b and anti-CD11c antibodies, respectively, followed by incorporation with biotin- coated iron beads and exposure to a magnetic field for $10 \mathrm{~min}$.

Total messenger RNA (mRNA) will be extracted from cells using the Reliaprep RNA Tissue Miniprep System RNA extraction kit (Promega, Madison, WI, USA), following the manufacturer's recommendations. After extraction, the precipitated RNA will be solubilized in $20 \mu \mathrm{L}$ of diethylpyrocarbonate (DEPC)-treated water. The total RNA concentration will be measured by spectrophotometry in a Nanodrop ND-1000 system. The integrity of the samples will be verified by $1 \%$ agarose gel electrophoresis containing $0.5 \mu \mathrm{g} / \mathrm{mL}$ of ethidium bromide. First-strand complementary DNA (cDNA) will be obtained from total RNA using the High Capacity cDNA Reverse Transcription kit (Invitrogen, CA, USA). Relative mRNA levels will be measured using BRYT Green (Promega, Fitchburg, WI, USA) using a Mastercycler ep Realplex PCR system (Eppendorf, Hamburg, Germany). All experiments will be performed in triplicates. Growth factors and inflammatory mediators will be analyzed by real-time RT-PCR. The relative level of each gene will be normalized to the housekeeping gene acidic ribosomal phosphoprotein P0 (36B4) and expressed as fold change relative to each individual at initial conditions, using the $2^{-\Delta \Delta}$ cycle threshold (Ct) method, where $\Delta \mathrm{Ct}=\mathrm{Ct}$ (target gene) $-\mathrm{Ct}$ (housekeeping gene). Neutrophil and macrophage gene expression in vitro will be analyzed by an investigator blinded to group assignment.

\section{Study endpoints \\ Primary}

The primary endpoint is the difference in plasma levels of IL- 6 when comparing patients anesthetized with sevoflurane versus propofol.

\section{Secondary}

The secondary endpoints are (1) the differences in levels of other proinflammmatory and anti-inflammatory mediators in blood, subcutaneous tissue, and visceral adipose tissue, namely (a) inflammatory mediators associated with neutrophils: metalloprotease (MMP)-2 [36-38], MMP-9 [36], CXCR2 [39], IL-12 [40], CCL3 (macrophage inflammatory protein (MIP)-1 $\alpha$ ) [41-44], CCL2 (MCP1) [44], IL-1 $\beta$ [45], TNF- $\alpha$ [46], NRF2 [47, 48], (b) mediators associated with macrophages: proinflammatory (IL-1 $\beta$, CD40 [49], CD80 [50]), M1 phenotype markers (TNF- $\alpha$, IL-6 [51-53], iNOS [54-56]), anti-inflammatory (IL-1 receptor antagonist (IL-1RA) [57-59], NrF2), M2 phenotype markers (CD163 [60, 61], CD206 [62], arginase [63, 64], IL-10 [65], transforming growth factor (TGF)- $\beta 1$ [66-68]), and (c) mediators associated with cell death pathways (BCL2-associated X (Bax), bcl2 [69, 70], caspases 3 and 9 [71-73]); (2) intraoperative complications: (a) hypoxemia $\left(\mathrm{PaO}_{2} / \mathrm{FiO}_{2}\right.$ ratio <300), (b) hypotension (systolic blood pressure $<90 \mathrm{mmHg}$ ), (c) bradycardia (heart rate $<50$ bpm), (d) unexpected need for intensive care unit (ICU) admission or readmission, (e) length of hospital stay, (f) number of days at home in the first month after surgery, and (g) postoperative complications: pulmonary infection (defined as new or progressive radiographic infiltrate and at least two of the following criteria - antibiotic treatment, axillary temperature $>38^{\circ} \mathrm{C}$, leukopenia (WBC $<4000$ cells $/ \mathrm{mm}^{3}$ ) or leukocytosis (WBC $>12,000$ cells $/ \mathrm{mm}^{3}$ ), and/or purulent secretions); sepsis (defined as suspicion or certainty of infection and an acute increase $\geq 2$ points in the Sequential Organ Failure Assessment Score (SOFA) in response to an infection, representing organ dysfunction); septic shock (defined as sepsis plus need for vasopressor to maintain mean blood pressure $>65 \mathrm{mmHg}$ plus lactate $>2 \mathrm{mmol} / \mathrm{L}[18 \mathrm{mg} / \mathrm{dL}]$ after adequate volume resuscitation [74-76]); extrapulmonary infection (of the operative wound or any other infection); coma (Glasgow Coma Scale $<8$ in the absence of therapeutic sedation); acute myocardial infarction (according to the universal definition thereof [77]); acute kidney failure (according to the risk, injury, failure, loss, end-stage renal failure (RIFLE) criteria classification system [78]); DIC (according to the International System for the Evaluation of Thrombosis and Hemostasis for DIC [79]); GIF (defined according to the GIF score [80]); acute liver failure (defined as a ratio of total bilirubin on the 5 th postoperative day to the 1 st postoperative day $>1.7$ plus a ratio of international normalized ratio (INR) on the 5th postoperative day to the 1st postoperative day $>1.0$ or presence of hepatic encephalopathy and INR > 1.5) [81, 82].

\section{Statistical analysis}

Positive modulation of the IL- 6 receptor and IL- 6 expression in adipose tissue is known to occur in obesity 
[51, 83]. A convenience sample of 48 patients has been chosen on the basis of a study in which plasma IL-6 levels were compared before and after anesthesia in patients undergoing thoracic surgery with one-lung ventilation [84]. The sample size was calculated using G*Power 3.1.9.2 software (University of Dusseldorf, Germany), taking into account an effect size of 1.33, a two-sided test, and a ratio of 1 . A sample size of 10 patients in each group will provide adequate power (80\%), assuming $\alpha=0.05$, to detect at least an effect size of 33\% difference in IL-6 levels in plasma samples collected immediately after induction of anesthesia and before extubation in obese patients anesthetized with sevoflurane or propofol $(p=0.05)$. Considering possible losses and to obtain even more significant results, we chose to increase the sample to 24 patients per group. Data will be tested for normality and variability. Comparison of the parameters of interest between participants in the sevoflurane and propofol groups will be performed by Student's $t$ test or the Wilcoxon test, as appropriate. Statistical significance will be accepted at $p<0.05$. All analyses will be undertaken by an independent statistician, who will be blinded to group allocation.

\section{Discussion}

The worldwide epidemic of obesity has become a major health problem. Obesity is known to feature a chronic inflammatory process, with increased levels of proinflammatory cytokines (TNF- $\alpha$, IL-6, IL-12), generation of reactive oxygen species, and greater differentiation of activated macrophages into the M1 phenotype [2, 3]. Macrophages are also associated with the development of insulin resistance and diabetes mellitus [85, 86]. Neutrophils are important components of the acute inflammatory response, constituting the first line of innate defense against infectious diseases. They also play a role in immune-response regulation [87], recruitment of macrophages and dendritic cells, and clearance of debris by means of phagocytosis $[87,88]$. In addition, they release antimicrobial molecules and neutrophil extracellular traps (NETs), which degrade bacterial virulence factors and kill extracellular bacteria, binding to both Gram-negative and Gram-positive bacteria $[87,89]$.

As the obese population increases, so does the need for diagnostic or therapeutic interventions where anesthetic care and management of anesthetic agents are required. It is well-established that anesthesia and surgery provoke hemodynamic, metabolic, and inflammatory responses, even though the isolated effects of each cannot be easily understood. Understanding the immunomodulatory properties of anesthetics in the obese body would be very helpful in establishing better guidelines for anesthetic management of this population.

Immunomodulation may have a beneficial effect, since suppression of the exacerbated inflammatory response can avoid damage such as that caused by acute inflammation [90], or a deleterious effect, since it can prevent the body from neutralizing infectious pathogens. It is now known that anesthetic agents may compromise or enhance immune function [5].

There are several patient-related (and thus nonmodifiable) factors associated with increased incidence of postoperative complications after bariatric surgery: male sex, preoperative $B M I \geq 60 \mathrm{~kg} / \mathrm{m}^{2}$, open surgery, smoking within the last year, deep vein thrombosis, therapeutic anticoagulation, and serum albumin $<3.5 \mathrm{~g} / \mathrm{dL}$ [91]. The duration and invasiveness of the surgical procedure may affect the inflammatory response, thus increasing the risk of bias [91], and will therefore be taken into account in this trial; these factors will be individually analyzed post hoc to isolate their interference with the outcomes of interest. The role of positive end-expiratory pressure (PEEP) in mechanical ventilation during general anesthesia for surgery remains uncertain. An ongoing randomized clinical trial is testing two different levels of PEEP: $4 \mathrm{cmH}_{2} \mathrm{O}$ without recruitment maneuvers versus $12 \mathrm{cmH}_{2} \mathrm{O}$ with recruitment maneuvers $[35,92]$. In the present trial protocol, a PEEP of $5 \mathrm{cmH}_{2} \mathrm{O}$ is suggested based on a secondary analysis of the international multicenter LAS VEGAS study, restricted to obese patients [93].

To our knowledge, only one prospective study has compared the effect of anesthesia with sevoflurane on inflammation to that of TIVA with propofol, in 54 adults undergoing thoracic surgery with one-lung ventilation [22]. The authors observed that the increase in inflammatory mediators such as TNF- $\alpha$, IL-6, and monocyte chemoattractant protein 1 (MCP-1) was significantly blunted in the sevoflurane group. Sevoflurane was also associated with fewer postoperative adverse events [22]. A randomized controlled trial of 5400 patients, which compared volatile anesthetics to TIVA for elective cardiac surgery, showed that anesthesia with a volatile agent did not result in a significantly lower 1-year mortality rate compared to TIVA [94].

Moreover, in the experimental setting of obesity, a 1-h infusion of propofol resulted in increased airway resistance, atelectasis, and pulmonary inflammation mediated by increased TNF- $\alpha$ and IL- 6 in lung tissue, with depletion of antioxidative enzymes [17]. Based on this evidence, we hypothesize that anesthesia with sevoflurane will result in a weaker inflammatory response compared to anesthesia with propofol.

This study is the first step toward choosing an anesthetic strategy that is capable of reducing systemic inflammation in obese subjects (i.e., patients with chronic inflammation) undergoing laparoscopic bariatric surgery. Some studies have compared sevoflurane with propofol, but have focused on clinical consequences, such as intraoperative mean arterial pressure, eye opening, extubation, 
recovery from anesthesia, postoperative pain, and incidence and severity of postoperative nausea and vomiting (PONV) $[18,95]$, without understanding the mechanisms associated with clinical improvement.

Sevoflurane, a low-solubility inhaled anesthetic, is the first-line anesthetic agent of choice in Brazil. It has been shown to have a cardioprotective effect, preventing myocardial ischemia and arrhythmias [96], even though like other anesthetic agents it may cause hypotension [97]. A study determined that the minimal alveolar concentration (MAC) for sevoflurane needed to maintain the BIS at $<50$ in morbidly obese patients undergoing bariatric surgery [98] was $1.8-1.6 \%$, higher than those values previously reported in normal adult patients $(0.97 \%$; $95 \%$ CI $0.89-1.1 \%)$ and lower than those reported in children (2.8\%; 95\% CI 2.7-3.1\%), which justifies the minimal MAC of 1.0 defined for this protocol. Moreover, a double-blind randomized controlled trial in superobese patients $\left(\mathrm{BMI}>50 \mathrm{~kg} / \mathrm{m}^{2}\right)$, in which the performance, effectiveness, and recovery from anesthesia was compared for sevoflurane versus propofol in combination with remifentanil, showed that although both propofol and sevoflurane provided adequate general anesthesia, sevoflurane may be preferable in the superobese due to superior hemodynamic stability and faster recovery [18].

Our analysis of biomarkers of obesity-related inflammation will help to further characterize the influence of anesthetics on the inflammatory response in obese subjects undergoing laparoscopic bariatric surgery. Potentially relevant biomarkers related to neutrophils (MMP-2, MMP-9, CXCR2, IL-12, CCL3, CCL2, IL-1ß, TNF- $\alpha$, NRF2), macrophages (IL-6, IL- $1 \beta$, TNF- $\alpha$, iNOS, CD40, CD80, CD163, CD206, arginase, IL-10, IL-1RA, TGF- $\beta 1, \mathrm{NrF} 2$ ), and cell death pathways (bax, bcl2, caspase 3 , caspase 9) will be evaluated. Table 2 summarizes the main roles of these biomarkers and their potential relevance. This study will provide a better understanding of the molecular mechanisms involved in the interaction between anesthetics and the inflammatory response, including the differential polarization of monocytes/macrophages in obese patients undergoing surgery.

Although several studies $[17,26,33,99-104]$ have been conducted in the search for an ideal drug combination or anesthetic strategy for the obese population, no guidelines have been established for laparoscopic bariatric surgery, a complex procedure that has several perioperative and postoperative repercussions. Many of these complications are due in part to the inflammatory stimulus associated with obesity. Knowledge of the immunomodulatory profile of some commonly used anesthetic agents in the obese population undergoing laparoscopic bariatric surgery may improve perioperative management, possibly reducing surgical complications such as anastomosis dehiscence, airway hyperreactivity, respiratory infection, surgical wound infection, myocardial injury, and prolonged hospitalization, with the potential for impact on short-term and long-term outcomes.

One limitation of the current trial is that, due to the nature of the intervention, blinding is not possible during surgery; this could induce bias. Nevertheless, the primary endpoint of the trial is a laboratory value and all analyses will be carried out in blinded fashion. In addition, the protocol strictly controls all processes that may influence the primary outcome. The second limitation is the choice of agents used for induction of anesthesia (alfentanil, remifentanil, and midazolam), all of which may affect the inflammatory process $[8,105$, 106]. Therefore, we will strive whenever possible to minimize the interference of these anesthetics - for instance, by standardizing the use of opioids in both groups. Midazolam may not be the first-line induction agent of choice for morbidly obese patients, since its half-life is only 6 to $15 \mathrm{~min}$ [107]; however, hypnotic agent options for anesthetic induction in the sevoflurane group in this trial are extremely limited, since many of these agents (ketamine, dexmedetomidine, propofol) may also affect host immunomodulation [8], while systemic clearance of midazolam is unchanged in these patients [108]. Additionally, to avoid overlapping effects, we cannot use propofol in both groups. Due to ethical reasons, we are unable to use propofol alone as the anesthetic agent for bariatric surgery, since its analgesic properties are considered insufficient. The use of sevoflurane alone in morbidly obese patients is also not recommended; since these patients must be ventilated prior to intubation, the stomach may fill with air if an inhaled agent is used for induction, thus increasing the risk of regurgitation and aspiration of gastric content. Therefore, rapid sequence induction (which consists of the intravenous administration in rapid succession of both a quick-onset anesthetic induction agent and a fast-acting muscle relaxant) has been recommended in this setting [109].

The opioid dose proposed in the protocol may be an additional point of concern. Opioid-free analgesia is increasingly popular and has numerous advantages, including lower healthcare resource utilization, lower postoperative opioid requirements, and lower rates of postoperative nausea and vomiting [110, 111]. However, opioid-free narcosis with ketamine or dexmedetomidine would interfere with our results and potentially lead to confounding and bias, since these drugs also have immunomodulatory properties, as noted previously.

Finally, we would like to include patients with a wider range of clinically relevant comorbidities which are highly prevalent in the obese population, including insulin-dependent diabetes mellitus, chronic kidney disease requiring renal replacement therapy, and cardiac 
Table 2 Biomarkers related to obesity and their relevance in the inflammatory response

\begin{tabular}{|c|c|c|}
\hline Biomarkers & Relevance & References \\
\hline MMP-2 & $\begin{array}{l}\text { Ability to break down ECM. Potential role as activator or inhibitor in tissue remodeling, atherosclerosis, } \\
\text { cardiovascular diseases, and obesity. Levels are increased in obesity }\end{array}$ & {$[36-38]$} \\
\hline MMP-9 & $\begin{array}{l}\text { Ability to break down ECM. Potential role as activator or inhibitor in tissue remodeling, cardiovascular diseases, and } \\
\text { obesity. Levels are diminished in obesity }\end{array}$ & [36] \\
\hline CXCR2 & Expressed on circulating neutrophils; critical for directing their migration to inflammatory sites & [39] \\
\hline IL-12 & $\begin{array}{l}\text { Associated with insulin resistance. Divergently regulated in relation to inflammatory stress, excessive energy intake, } \\
\text { and genetic obesity }\end{array}$ & [40] \\
\hline CCL3 (MIP-1a) & $\begin{array}{l}\text { High transcript and protein levels in the white adipose tissue of the obese. Correlated with fasting plasma insulin } \\
\text { concentrations in humans. Required for macrophage infiltration in adipose tissue with CCL2 }\end{array}$ & [41-44] \\
\hline CCL2 (MCP1) & $\begin{array}{l}\text { Required for macrophage infiltration of adipose tissue Adipose-tissue and serum CCL2 expression is increased } \\
\text { through insulin stimuli, more in insulin-resistant than in insulin-sensitive lean mice }\end{array}$ & [44] \\
\hline IL-1 $\beta$ & $\begin{array}{l}\text { Produced by macrophages. Implicated in the development of obesity-associated insulin resistance through inhib- } \\
\text { ition of insulin signal transduction }\end{array}$ & [45] \\
\hline TNF-a & $\begin{array}{l}\text { Expressed and secreted by adipose tissue. Levels associated with degree of adiposity and insulin resistance. } \\
\text { Targeting TNF-a and/or its receptors has been suggested as a promising treatment for insulin resistance and type } 2 \\
\text { diabetes mellitus }\end{array}$ & [46] \\
\hline Nrf2 & $\begin{array}{l}\text { Involved in resistance to oxidative stress. Functions as a xenobiotic-activated receptor (XAR) to regulate the adaptive } \\
\text { response to oxidants }\end{array}$ & {$[47,48]$} \\
\hline IL-6 & $\begin{array}{l}\text { Pleiotropic cytokine. A central player in the regulation of inflammation, hematopoiesis, immune responses, and host } \\
\text { defense mechanisms. Influences secretion of adipokines from adipocytes. Involved in the etiology of obesity-related } \\
\text { comorbidities, including insulin resistance and accelerated atherosclerosis, in humans }\end{array}$ & {$[51-53]$} \\
\hline iNOS & $\begin{array}{l}\text { Synthesizes large quantities of nitric oxide (NO), which acts with reactive oxidative species to producing nitrosative } \\
\text { stress, thus playing a key role in adipocyte function and glucose tolerance }\end{array}$ & [54-56] \\
\hline CD 40 & Ameliorates inflammation in visceral adipose tissue. Attenuates obesity-induced insulin resistance & [49] \\
\hline CD 80 & Plays a homeostatic role in preventing adipose inflammation & [50] \\
\hline ICAM-1 & Levels increased in obesity. Positively correlated with central adiposity and insulin resistance & {$[50,51]$} \\
\hline CD 163 & $\begin{array}{l}\text { Marker of macrophages with anti-inflammatory properties. Increased basal CD163 levels are related to obesity and } \\
\text { its metabolic complications }\end{array}$ & {$[60,61]$} \\
\hline CD 206 & $\begin{array}{l}\text { Marker of M2-like macrophages in adipose tissues. Inhibits growth and differentiation of adipocyte progenitors, thus } \\
\text { controlling adiposity and systemic insulin sensitivity }\end{array}$ & [62] \\
\hline Arginase & Marker of M2 macrophages. Also expressed in endothelial cells. Involved in obesity-induced vascular dysfunction & {$[63,64]$} \\
\hline IL-10 & $\begin{array}{l}\text { Anti-inflammatory cytokine. High levels found in obese women. Low levels are associated with the metabolic } \\
\text { syndrome }\end{array}$ & [65] \\
\hline IL-1RA & $\begin{array}{l}\text { Indirectly elicits an anti-inflammatory response. Competitively binds to the IL-1 receptor on the cell surface, thereby } \\
\text { inhibiting the inflammatory effects of IL-1 }\end{array}$ & [57-59] \\
\hline TGF- $\beta 1$ & $\begin{array}{l}\text { Anti-inflammatory cytokine. Counteracts the effects of the pro-inflammatory cytokines such as IL-8. Inhibits differen- } \\
\text { tiation of pre-adipocytes }\end{array}$ & [66-68] \\
\hline $\mathrm{Bax}, \mathrm{BCl}-2$ & $\begin{array}{l}\text { Part of the Bcl-2 family of proteins, which constitute a cell-death pathway. } \mathrm{BCl}-2 \text { is a death antagonist, and Bax, a } \\
\text { death agonist. The setpoint that determines cell susceptibility to apoptosis is determined by the ratio of these mol- } \\
\text { ecules. Related to brown adipose tissue atrophy (BAT) in obesity, in part due to apoptosis of adipocytes }\end{array}$ & {$[69,70]$} \\
\hline $\begin{array}{l}\text { Caspase } 3 \text { and } \\
\text { Caspase } 9\end{array}$ & $\begin{array}{l}\text { Mediate the inflammatory response and apoptotic cell death to maintain homeostasis. Caspase-dependent apop- } \\
\text { tosis is involved in the pathogenesis of obesity and progression of severe nonalcoholic steatohepatitis (NASH). Cas- } \\
\text { pase } 9 \text { is an initiator and caspase } 3 \text { is an executioner of cell death }\end{array}$ & [71-73] \\
\hline
\end{tabular}

MMP-2 metalloproteinase-2, ECM extracellular matrix, MMP-9 metalloproteinase-9, CXCR2 CXC chemokine receptor 2, IL-12 interleukin-12, CCL3 C-C motif chemokine ligand 3, MIP-1 macrophage inflammatory protein, CCL2 C-C motif chemokine ligand 2, MCP1 monocyte chemoattractant protein-1, IL-1 $\beta$ interleukin$1 \beta, T N F-a$ tumor necrosis factor alpha, Nrf2 nuclear factor (erythroid-derived 2)-like 2, IL-6 interleukin-6, iNOS inducible nitric oxide synthase, CD 40 cluster of differentiation 40, CD 80 cluster of differentiation 80, ICAM-1 intercellular adhesion molecule 1, CD 163 cluster of differentiation 163, CD 206 cluster of differentiation 206, IL-10 interleukin-10, IL-1RA interleukin 1 receptor antagonist, TGF- $\beta 1$ transforming growth factor beta 1, Bax BCL2-associated X, BCl-2 B-cell lymphoma 2

impairment (NYHA III-IV). Unfortunately, inclusion of these patients could also result in bias, as these conditions are all associated with greater systemic inflammation than is found in otherwise "healthy" morbidly obese patients (i.e., those without comorbidities) [112-115].
This is not a conclusive trial; it is a pilot study that aims to compile evidence of whether a further, larger study powered for hard-outcome assessment would be feasible in obese patients undergoing bariatric surgery. The upcoming results of this trial would enable the 
authors to prepare a larger, well-designed parallel study assessing the influence of both anesthetics on core clinical endpoints, such as mortality and morbidity, and further analyses of the immunological factors of each anesthetic once clinical endpoints are determined.

In conclusion, this randomized controlled pilot trial aims to test the hypothesis that anesthesia with sevoflurane compared to propofol in obese patients undergoing laparoscopic bariatric surgery will promote a weaker inflammatory response, as reflected by levels of IL- 6 and several other parameters. This is the first study to evaluate the impact of two widely used anesthetics on the inflammatory response and their immunomodulatory properties, in addition to clinical, hemodynamic, and ventilatory outcomes, in obese patients undergoing laparoscopic bariatric surgery. Whatever the results of the trial, performing a prospective, randomized study in this setting could provide scientific evidence on the immune effects of these commonly used anesthetic agents in the obese population.

\section{Additional file}

Additional file 1: Standard Protocol Items: Recommendations for Interventional Trials (SPIRIT) 2013 Checklist: recommended items to address in a clinical trial protocol and related documents. (DOC $124 \mathrm{~kb}$ )

\section{Acknowledgements}

We would like to thank Mrs Moira Elizabeth Schottler and Mr Filippe Vasconcellos for their assistance in editing the manuscript and Prof. Ronir Raggio Luiz for his help with statistics.

\section{Funding}

This study is supported by the Brazilian Council for Scientific and Technological Development (CNPq), the Rio de Janeiro State Research Foundation (FAPERJ), the São Paulo State Research Foundation (FAPESP), the National Institute of Science and Technology for Regenerative Medicine (INCT-REGENERA), and the Coordination for the Improvement of Higher Education Personnel (CAPES).

\section{Availability of data and materials}

The datasets analyzed during the present study are available from the corresponding author on reasonable request.

\section{Authors' contributions}

GCS, FFC, LBH, CJSS, FS, MJS, PP, MGA, PLS, and PRMR conceived and designed the study, will coordinate the overall study, and drafted the manuscript. GCS, MGA, and PLS performed the power calculations and designed the statistical analysis plan. GCS, LBH, MJS, MGA, PP, and PRMR prepared the initial draft of this manuscript. All authors contributed to manuscript writing and read and approved the final version.

\section{Authors' information}

Not applicable.

\section{Ethics approval and consent to participate}

The institutional review board (IRB) at the D'Or Institute for Research and Education (IDOR) approved the study protocol (reference no. 93400518.1.0000.5249). The OBESITA is designed in accordance with the principles of the Declaration of Helsinki. Written informed consent will be obtained from every patient before enrollment.

Consent for publication

Not applicable.

\section{Competing interests}

The authors declare that they have no competing interests.

\section{Publisher's Note}

Springer Nature remains neutral with regard to jurisdictional claims in published maps and institutional affiliations.

\section{Author details}

'Laboratory of Pulmonary Investigation, Carlos Chagas Filho Institute of Biophysics, Federal University of Rio de Janeiro, Centro de Ciências da Saúde, Avenida Carlos Chagas Filho, 373, Bloco G1-014, Ilha do Fundão, Rio de Janeiro 21941-902, Brazil. ${ }^{2}$ Department of Anesthesiology, Federal University of Rio de Janeiro, Rio de Janeiro, Brazil. ${ }^{3}$ Institute D'Or of Research and Teaching, Rio de Janeiro, Brazil. ${ }^{4}$ Department of Intensive Care and Laboratory of Experimental Intensive Care and Anesthesiology (L.E.I.C.A), Amsterdam University Medical Centers, University of Amsterdam, Amsterdam, The Netherlands. ${ }^{5}$ Mahidol Oxford Tropical Medicine Research Unit (MORU), Faculty of Tropical Medicine, Mahidol University, Bangkok, Thailand. ${ }^{6}$ Department of Surgical Sciences and Integrated Diagnostics, University of Genoa, Genoa, Italy. ${ }^{7}$ Ospedale Policlinico San Martino, IRCCS for Oncology and Neurosciences, Genoa, Italy. ${ }^{8}$ Pulmonary Engineering Group, Department of Anesthesiology and Intensive Care Medicine, University Hospital Carl Gustav Carus, Dresden, Germany.

Received: 30 October 2018 Accepted: 6 May 2019

Published online: 28 May 2019

\section{References}

1. Abdelaal M, le Roux CW, Docherty NG. Morbidity and mortality associated with obesity. Ann Transl Med. 2017;5(7):161.

2. Lumeng CN, Bodzin JL, Saltiel AR. Obesity induces a phenotypic switch in adipose tissue macrophage polarization. J Clin Invest. 2007;117(1):175-84.

3. Cancello R, Henegar C, Viguerie N, Taleb S, Poitou C, Rouault C, Coupaye M, Pelloux V, Hugol D, Bouillot $J$, et al. Reduction of macrophage infiltration and chemoattractant gene expression changes in white adipose tissue of morbidly obese subjects after surgery-induced weight loss. Diabetes. 2005; 54(8):2277-86.

4. Thomas D, Apovian C. Macrophage functions in lean and obese adipose tissue. Metabolism. 2017;72:120-43.

5. Heil LBB, Silva PL, Pelosi P, Rocco PRM. Immunomodulatory effects of anesthetics in obese patients. World J Crit Care Med. 2017;6(3):140-52

6. Mazoti MA, Braz MG, de Assis Golim M, Braz LG, Dias NH, Salvadori DM, Braz $J R$, Fecchio D. Comparison of inflammatory cytokine profiles in plasma of patients undergoing otorhinological surgery with propofol or isoflurane anesthesia. Inflamm Res. 2013;62(10):879-85.

7. Schneemilch CE, Ittenson A, Ansorge S, Hachenberg T, Bank U. Effect of 2 anesthetic techniques on the postoperative proinflammatory and antiinflammatory cytokine response and cellular immune function to minor surgery. J Clin Anesth. 2005;17(7):517-27.

8. Cruz FF, Rocco PR, Pelosi P. Anti-inflammatory properties of anesthetic agents. Crit Care. 2017;21(1):67.

9. Watanabe K, Iwahara C, Nakayama H, Iwabuchi K, Matsukawa T, Yokoyama K, Yamaguchi K, Kamiyama Y, Inada E. Sevoflurane suppresses tumour necrosis factor-alpha-induced inflammatory responses in small airway epithelial cells after anoxia/reoxygenation. Br J Anaesth. 2013;110(4):637-45.

10. Loop T, Scheiermann P, Doviakue D, Musshoff F, Humar M, Roesslein M, Hoetzel A, Schmidt R, Madea B, Geiger KK, et al. Sevoflurane inhibits phorbol-myristate-acetate-induced activator protein-1 activation in human T lymphocytes in vitro: potential role of the p38-stress kinase pathway. Anesthesiology. 2004;101(3):710-21.

11. Stollings $L M$, Jia $L J$, Tang $P$, Dou $H$, Lu B, Xu Y. Immune modulation by volatile anesthetics. Anesthesiology. 2016;125(2):399-411.

12. Lee $\mathrm{YM}$, Song $B C$, Yeum KJ. Impact of volatile anesthetics on oxidative stress and inflammation. Biomed Res Int. 2015;2015:242709.

13. Yang SC, Chung PJ, Ho CM, Kuo CY, Hung MF, Huang YT, Chang WY, Chang YW, Chan KH, Hwang TL. Propofol inhibits superoxide production, elastase release, and chemotaxis in formyl peptide-activated human neutrophils by blocking formyl peptide receptor 1.J Immunol. 2013;190(12):6511-9.

14. Frohlich D, Trabold B, Rothe G, Hoerauf K, Wittmann S. Inhibition of the neutrophil oxidative response by propofol: preserved in vivo function despite in vitro inhibition. Eur J Anaesthesiol. 2006;23(11):948-53. 
15. Shiratsuchi H, Kouatli Y, Yu GX, Marsh HM, Basson MD. Propofol inhibits pressurestimulated macrophage phagocytosis via the GABAA receptor and dysregulation of p130cas phosphorylation. Am J Physiol Cell Physiol. 2009;296(6):C1400-10.

16. Visvabharathy L, Xayarath B, Weinberg G, Shilling RA, Freitag NE. Propofol increases host susceptibility to microbial infection by reducing subpopulations of mature immune effector cells at sites of infection. PLoS One. 2015;10(9):e0138043.

17. Heil LB, Santos CL, Santos RS, Samary CS, Cavalcanti VC, Araujo MM, Poggio H, Maia Lde A, Trevenzoli IH, Pelosi P, et al. The effects of short-term propofol and dexmedetomidine on lung mechanics, histology, and biological markers in experimental obesity. Anesth Analg. 2016;122(4):1015-23.

18. Siampalioti A, Karavias D, Zotou A, Kalfarentzos F, Filos K. Anesthesia management for the super obese: is sevoflurane superior to propofol as a sole anesthetic agent? A double-blind randomized controlled trial. Eur Rev Med Pharmacol Sci. 2015;19(13):2493-500

19. Gaszynski T, Wieczorek A. A comparison of BIS recordings during propofol-based total intravenous anaesthesia and sevoflurane-based inhalational anaesthesia in obese patients. Anaesthesiol Intensive Ther. 2016:48(4):239-47.

20. Poirier $P$, Cornier MA, Mazzone T, Stiles S, Cummings S, Klein S, McCullough PA, Ren Fielding C, Franklin BA. Bariatric surgery and cardiovascular risk factors: a scientific statement from the American Heart Association. Circulation. 2011;123(15):1683-701.

21. Birkmeyer NJ, Dimick JB, Share D, Hawasli A, English WJ, Genaw J, Finks JF, Carlin AM, Birkmeyer JD. Hospital complication rates with bariatric surgery in Michigan. JAMA. 2010;304(4):435-42.

22. De Conno E, Steurer MP, Wittlinger M, Zalunardo MP, Weder W, Schneiter D, Schimmer RC, Klaghofer R, Neff TA, Schmid ER, et al. Anesthetic-induced improvement of the inflammatory response to one-lung ventilation. Anesthesiology. 2009;110(6):1316-26.

23. Schulz KF, Altman DG, Moher D. CONSORT 2010 statement: updated guidelines for reporting parallel group randomised trials. BMJ. 2010; 340:c332.

24. Canet J, Gallart L, Gomar C, Paluzie G, Valles J, Castillo J, Sabate S, Mazo V, Briones Z, Sanchis J. Prediction of postoperative pulmonary complications in a population-based surgical cohort. Anesthesiology. 2010;113(6):1338-50.

25. Sperandio EF, Arantes RL, Matheus AC, Silva RP, Lauria VT, Romiti M, Gagliardi AR, Dourado VZ. Restrictive pattern on spirometry: association with cardiovascular risk and level of physical activity in asymptomatic adults. J Bras Pneumol. 2016;42(1):22-8.

26. Cortinez LI, De la Fuente N, Eleveld DJ, Oliveros A, Crovari F, Sepulveda P, Ibacache M, Solari S. Performance of propofol target-controlled infusion models in the obese: pharmacokinetic and pharmacodynamic analysis. Anesth Analg. 2014;119(2):302-10.

27. Wool DB, Lemmens HJ, Brodsky JB, Solomon H, Chong KP, Morton JM. Intraoperative fluid replacement and postoperative creatine phosphokinase levels in laparoscopic bariatric patients. Obes Surg. 2010;20(6):698-701.

28. Ingrande J, Brodsky JB. Intraoperative fluid management and bariatric surgery. Int Anesthesiol Clin. 2013;51(3):80-9.

29. De Baerdemaeker LEC, Mortier EP, Struys MMRF. Pharmacokinetics in obese patients. Contin Educ Anaesth Crit Care Pain. 2004;4(5):152-5.

30. Casati A, Putzu M. Anesthesia in the obese patient: pharmacokinetic considerations. J Clin Anesth. 2005;17(2):134-45.

31. Ingrande J, Lemmens HJ. Dose adjustment of anaesthetics in the morbidly obese. Br J Anaesth. 2010;105(Suppl 1):116-23.

32. Murphy GS. Neuromuscular monitoring in the perioperative period. Anesth Analg. 2018;126(2):464-8.

33. Van Lancker P, Dillemans B, Bogaert T, Mulier JP, De Kock M, Haspeslagh M. Ideal versus corrected body weight for dosage of sugammadex in morbidly obese patients. Anaesthesia. 2011;66(8):721-5.

34. Nightingale CE, Margarson MP, Shearer E, Redman JW, Lucas DN, Cousins JM, Fox WT, Kennedy NJ, Venn PJ, Skues M, et al. Peri-operative management of the obese surgical patient 2015: Association of Anaesthetists of Great Britain and Ireland Society for Obesity and Bariatric Anaesthesia. Anaesthesia. 2015;70(7):859-76.

35. Bluth T, Teichmann R, Kiss T, Bobek I, Canet J, Cinnella G, De Baerdemaeker L, Gregoretti C, Hedenstierna G, Hemmes SN, et al. Protective intraoperative ventilation with higher versus lower levels of positive end-expiratory pressure in obese patients (PROBESE): study protocol for a randomized controlled trial. Trials. 2017;18(1):202.
36. Jaoude J, Koh Y. Matrix metalloproteinases in exercise and obesity. Vasc Health Risk Manag. 2016;12:287-95.

37. Gielen S, Schuler G, Adams V. Cardiovascular effects of exercise training: molecular mechanisms. Circulation. 2010;122(12):1221-38.

38. Chavey C, Mari B, Monthouel MN, Bonnafous S, Anglard P, Van Obberghen E, Tartare-Deckert S. Matrix metalloproteinases are differentially expressed in adipose tissue during obesity and modulate adipocyte differentiation. J Biol Chem. 2003;278(14):11888-96.

39. Mishra HK, Long C, Bahaie NS, Walcheck B. Regulation of CXCR2 expression and function by a disintegrin and metalloprotease-17 (ADAM17). J Leukoc Biol. 2015;97(3):447-54.

40. Nam H, Ferguson BS, Stephens JM, Morrison RF. Impact of obesity on IL-12 family gene expression in insulin responsive tissues. Biochim Biophys Acta. 2013;1832(1):11-9.

41. Surmi BK, Webb CD, Ristau AC, Hasty AH. Absence of macrophage inflammatory protein-1\{alpha\} does not impact macrophage accumulation in adipose tissue of diet-induced obese mice. Am J Phys Endocrinol Metab. 2010;299(3):E437-45.

42. Huber J, Kiefer FW, Zeyda M, Ludvik B, Silberhumer GR, Prager G, Zlabinger GJ, Stulnig TM. CC chemokine and CC chemokine receptor profiles in visceral and subcutaneous adipose tissue are altered in human obesity. J Clin Endocrinol Metab. 2008;93(8):3215-21.

43. Murdolo G, Hammarstedt A, Sandqvist M, Schmelz M, Herder C, Smith U, Jansson PA. Monocyte chemoattractant protein-1 in subcutaneous abdominal adipose tissue: characterization of interstitial concentration and regulation of gene expression by insulin. J Clin Endocrinol Metab. 2007; 92(7):2688-95

44. Westerbacka J, Corner A, Kolak M, Makkonen J, Turpeinen U, Hamsten A, Fisher RM, Yki-Jarvinen $\mathrm{H}$. Insulin regulation of MCP-1 in human adipose tissue of obese and lean women. Am J Phys Endocrinol Metab. 2008;294(5): E841-5.

45. Bing C. Is interleukin-1 beta a culprit in macrophage-adipocyte crosstalk in obesity? Adipocyte. 2015;4(2):149-52.

46. Tzanavari T, Giannogonas P, Karalis KP. TNF-alpha and obesity. Curr Dir Autoimmun. 2010;11:145-56

47. Ma Q. Role of nrf2 in oxidative stress and toxicity. Annu Rev Pharmacol Toxicol. 2013;53:401-26.

48. $\mathrm{Ma} \mathrm{Q}$. Xenobiotic-activated receptors: from transcription to drug metabolism to disease. Chem Res Toxicol. 2008;21(9):1651-71.

49. Yi Z, Bishop GA. Regulatory role of CD40 in obesity-induced insulin resistance. Adipocyte. 2015;4(1):65-9.

50. Zhong J, Rao X, Braunstein Z, Taylor A, Narula V, Hazey J, Mikami D, Needleman B, Rutsky J, Sun Q, et al. T-cell costimulation protects obesityinduced adipose inflammation and insulin resistance. Diabetes. 2014;63(4): 1289-302.

51. Eder K, Baffy N, Falus A, Fulop AK. The major inflammatory mediator interleukin-6 and obesity. Inflamm Res. 2009;58(11):727-36.

52. Akira S, Taga T, Kishimoto T. Interleukin-6 in biology and medicine. Adv Immunol. 1993:54:1-78.

53. Wallenius V, Wallenius K, Ahren B, Rudling M, Carlsten H, Dickson SL, Ohlsson C, Jansson JO. Interleukin-6-deficient mice develop mature-onset obesity. Nat Med. 2002;8(1):75-9.

54. Becerril S, Rodriguez A, Catalan V, Mendez-Gimenez L, Ramirez B, Sainz N, Llorente M, Unamuno X, Gomez-Ambrosi J, Fruhbeck G. Targeted disruption of the iNOS gene improves adipose tissue inflammation and fibrosis in leptin-deficient ob/ob mice: role of tenascin C. Int J Obes. 2018;42(8):1458-70.

55. Furukawa S, Fujita T, Shimabukuro M, Iwaki M, Yamada $Y$, Nakajima $Y$, Nakayama O, Makishima M, Matsuda M, Shimomura I. Increased oxidative stress in obesity and its impact on metabolic syndrome. J Clin Invest. 2004; 114(12):1752-61.

56. Kaneki M, Shimizu N, Yamada D, Chang K. Nitrosative stress and pathogenesis of insulin resistance. Antioxid Redox Signal. 2007;9(3):319-29.

57. Charles BA, Doumatey A, Huang H, Zhou J, Chen G, Shriner D, Adeyemo A, Rotimi CN. The roles of IL-6, IL-10, and IL-1RA in obesity and insulin resistance in African-Americans. J Clin Endocrinol Metab. 2011;96(12):E2018-22.

58. Juge-Aubry CE, Henrichot E, Meier CA. Adipose tissue: a regulator of inflammation. Best Pract Res Clin Endocrinol Metab. 2005;19(4):547-66.

59. Mandrup-Poulsen T, Zumsteg U, Reimers J, Pociot F, Morch L, Helqvist S, Dinarello CA, Nerup J. Involvement of interleukin 1 and interleukin 1 
antagonist in pancreatic beta-cell destruction in insulin-dependent diabetes mellitus. Cytokine. 1993;5(3):185-91.

60. Cinkajzlova A, Lacinova Z, Klouckova J, Kavalkova P, Trachta P, Kosak M, Kratky J, Kasalicky M, DoleZalova K, Mraz M, et al. An alternatively activated macrophage marker CD163 in severely obese patients: the influence of very low-calorie diet and bariatric surgery. Physiol Res. 2017;66(4):641-52

61. Schaer CA, Schoedon G, Imhof A, Kurrer MO, Schaer DJ. Constitutive endocytosis of CD163 mediates hemoglobin-heme uptake and determines the noninflammatory and protective transcriptional response of macrophages to hemoglobin. Circ Res. 2006;99(9):943-50.

62. Nawaz A, Aminuddin A, Kado T, Takikawa A, Yamamoto S, Tsuneyama K, Igarashi Y, Ikutani M, Nishida Y, Nagai Y, et al. CD206(+) M2-like macrophages regulate systemic glucose metabolism by inhibiting proliferation of adipocyte progenitors. Nat Commun. 2017;8(1):286

63. Yao L, Bhatta A, Xu Z, Chen J, Toque HA, Chen Y, Xu Y, Bagi Z, Lucas $R$, Huo $Y$, et al. Obesity-induced vascular inflammation involves elevated arginase activity. Am J Physiol Regul Integr Comp Physiol. 2017;313(5): R560-71.

64. Johnson FK, Peyton KJ, Liu XM, Azam MA, Shebib AR, Johnson RA, Durante $W$. Arginase promotes endothelial dysfunction and hypertension in obese rats. Obesity (Silver Spring). 2015;23(2):383-90.

65. Esposito K, Pontillo A, Giugliano F, Giugliano G, Marfella R, Nicoletti G, Giugliano D. Association of low interleukin-10 levels with the metabolic syndrome in obese women. J Clin Endocrinol Metab. 2003; 88(3):1055-8.

66. Fain JN, Tichansky DS, Madan AK. Transforming growth factor beta1 release by human adipose tissue is enhanced in obesity. Metabolism. 2005;54(11):1546-51.

67. Zhou S, Lechpammer S, Greenberger JS, Glowacki J. Hypoxia inhibition of adipocytogenesis in human bone marrow stromal cells requires transforming growth factor-beta/Smad3 signaling. J Biol Chem. 2005;280(24):22688-96.

68. Shin SM, Kim K, Kim JK, Yoon SR, Choi I, Yang Y. Dexamethasone reverses TGF-beta-mediated inhibition of primary rat preadipocyte differentiation. FEBS Lett. 2003;543(1-3):25-30.

69. Knudson CM, Korsmeyer SJ. BCl-2 and Bax function independently to regulate cell death. Nat Genet. 1997;16(4):358-63.

70. Briscini L, Tonello C, Dioni L, Carruba MO, Nisoli E. BCl-2 and Bax are involved in the sympathetic protection of brown adipocytes from obesity-linked apoptosis. FEBS Lett. 1998;431(1):80-4.

71. Wilson $\mathrm{CH}$, Kumar S. Caspases in metabolic disease and their therapeutic potential. Cell Death Differ. 2018;25(6):1010-24.

72. Shalini S, Dorstyn L, Dawar S, Kumar S. Old, new and emerging functions of caspases. Cell Death Differ. 2015;22(4):526-39.

73. Alkhouri N, Gornicka A, Berk MP, Thapaliya S, Dixon LJ, Kashyap S, Schauer PR, Feldstein AE. Adipocyte apoptosis, a link between obesity, insulin resistance, and hepatic steatosis. J Biol Chem. 2010; 285(5):3428-38.

74. Seymour CW, Liu VX, Iwashyna TJ, Brunkhorst FM, Rea TD, Scherag A, Rubenfeld G, Kahn JM, Shankar-Hari M, Singer M, et al. Assessment of clinical criteria for sepsis: for the Third International Consensus Definitions for Sepsis and Septic Shock (Sepsis-3). JAMA. 2016;315(8):762-74.

75. Shankar-Hari M, Phillips GS, Levy ML, Seymour CW, Liu VX, Deutschman CS, Angus DC, Rubenfeld GD, Singer M. Developing a new definition and assessing new clinical criteria for septic shock: for the Third International Consensus Definitions for Sepsis and Septic Shock (Sepsis-3). JAMA. 2016; 315(8):775-87

76. Vincent JL, Moreno R, Takala J, Willatts S, De Mendonca A, Bruining $H$, Reinhart CK, Suter PM, Thijs LG. The SOFA (Sepsis-related Organ Failure Assessment) score to describe organ dysfunction/failure. On behalf of the Working Group on Sepsis-Related Problems of the European Society of Intensive Care Medicine. Intensive Care Med. 1996;22(7):707-10.

77. Thygesen K, Alpert JS, White HD, Jaffe AS, Apple FS, Galvani M, Katus HA, Newby LK, Ravkilde J, Chaitman B, et al. Universal definition of myocardial infarction. Circulation. 2007;116(22):2634-53.

78. Bellomo R, Ronco C, Kellum JA, Mehta RL, Palevsky P. Acute renal failure definition, outcome measures, animal models, fluid therapy and information technology needs: the Second International Consensus Conference of the Acute Dialysis Quality Initiative (ADQI) Group. Crit Care. 2004;8(4):R204-12.
79. Levi M, Toh CH, Thachil J, Watson HG. Guidelines for the diagnosis and management of disseminated intravascular coagulation. British Committee for Standards in Haematology. Br J Haematol. 2009;145(1): 24-33.

80. Reintam A, Parm P, Kitus R, Starkopf J, Kern H. Gastrointestinal failure score in critically ill patients: a prospective observational study. Crit Care. 2008;12(4):R90.

81. Du ZG, Wei YG, Chen KF, Li B. An accurate predictor of liver failure and death after hepatectomy: a single institution's experience with 478 consecutive cases. World J Gastroenterol. 2014;20(1):274-81.

82. Wlodzimirow KA, Eslami S, Abu-Hanna A, Nieuwoudt M, Chamuleau RA. Systematic review: acute liver failure - one disease, more than 40 definitions. Aliment Pharmacol Ther. 2012;35(11):1245-56.

83. Sindhu S, Thomas R, Shihab P, Sriraman D, Behbehani K, Ahmad R. Obesity is a positive modulator of IL-6R and IL-6 expression in the subcutaneous adipose tissue: significance for metabolic inflammation. PLoS One. 2015; 10(7):e0133494.

84. Schilling T, Kozian A, Senturk M, Huth C, Reinhold A, Hedenstierna G, Hachenberg T. Effects of volatile and intravenous anesthesia on the alveolar and systemic inflammatory response in thoracic surgical patients. Anesthesiology. 2011;115(1):65-74.

85. Fried SK, Bunkin DA, Greenberg AS. Omental and subcutaneous adipose tissues of obese subjects release interleukin-6: depot difference and regulation by glucocorticoid. J Clin Endocrinol Metab. 1998;83(3):847-50.

86. Kershaw EE, Flier JS. Adipose tissue as an endocrine organ. J Clin Endocrinol Metab. 2004;89(6):2548-56.

87. Kumar V, Sharma A. Neutrophils: Cinderella of innate immune system. Int Immunopharmacol. 2010;10(11):1325-34.

88. Selders GS, Fetz AE, Radic MZ, Bowlin GL. An overview of the role of neutrophils in innate immunity, inflammation and host-biomaterial integration. Regen Biomater. 2017;4(1):55-68.

89. Brinkmann V, Reichard U, Goosmann C, Fauler B, Uhlemann Y, Weiss DS, Weinrauch Y, Zychlinsky A. Neutrophil extracellular traps kill bacteria. Science. 2004;303(5663):1532-5.

90. Medzhitov R. Origin and physiological roles of inflammation. Nature. 2008; 454(7203):428-35.

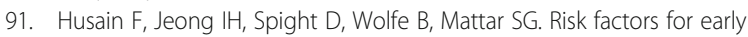
postoperative complications after bariatric surgery. Ann Surg Treat Res. 2018;95(2):100-10.

92. Bluth T, Teichmann R, Kiss T, Bobek I, Canet J, Cinnella G, De Baerdemaeker L, Gregoretti C, Hedenstierna G, Hemmes SN, et al. Erratum to Protective intraoperative ventilation with higher versus lower levels of positive endexpiratory pressure in obese patients (PROBESE): study protocol for a randomized controlled trial. Trials. 2017;18(1):247.

93. Ball L, Hemmes SNT, Serpa Neto A, Bluth T, Canet J, Hiesmayr M, Hollmann MW, Mills GH, Vidal Melo MF, Putensen C, et al. Intraoperative ventilation settings and their associations with postoperative pulmonary complications in obese patients. Br J Anaesth. 2018;121(4):899-908.

94. Landoni G, Lomivorotov W, Nigro Neto C, Monaco F, Pasyuga W, Bradic N, Lembo R, Gazivoda G, Likhvantsev W, Lei C, et al. Volatile anesthetics versus total intravenous anesthesia for cardiac surgery. N Engl J Med. 2019:380:1214-25.

95. Liu FL, Cherng YG, Chen SY, Su YH, Huang SY, Lo PH, Lee YY, Tam KW. Postoperative recovery after anesthesia in morbidly obese patients: a systematic review and meta-analysis of randomized controlled trials. Can J Anaesth. 2015;62(8):907-17.

96. Pagel PS, Farber NE. Inhaled anesthetics: cardiovascular pharmacology. In: Miller RD, editor. Miller's anesthesia, vol. 1. 8th ed. Philadelphia: Elsevier Saunders; 2015. p. 706.

97. Tsikas D, Jordan J, Engeli S. Blood pressure-lowering effects of propofol or sevoflurane anaesthesia are not due to enhanced nitric oxide formation or bioavailability. Br J Clin Pharmacol. 2015;79(6):1030-3.

98. Zeidan A, Mazoit JX. Minimal alveolar concentration of sevoflurane for maintaining bispectral index below 50 in morbidly obese patients. Acta Anaesthesiol Scand. 2013;57(4):474-9.

99. Abramo A, Di Salvo C, Baldi G, Marini E, Anselmino M, Salvetti G, Giunta F, Forfori F. Xenon anesthesia reduces TNFalpha and IL10 in bariatric patients. Obes Surg. 2012;22(2):208-12.

100. Roussabrov E, Davies JM, Bessler H, Greemberg L, Roytblat L, Yadeni IZ, Artru AA, Shapira Y. Effect of ketamine on inflammatory and immune responses after short-duration surgery in obese patients. Open Anesthesiology J. 2008;2:40-5. 
101. Brodsky JB, Lemmens HJ, Saidman LJ. Obesity, surgery, and inhalation anesthetics - is there a "drug of choice"? Obes Surg. 2006;16(6):734.

102. Vallejo MC, Sah N, Phelps AL, O'Donnell J, Romeo RC. Desflurane versus sevoflurane for laparoscopic gastroplasty in morbidly obese patients. J Clin Anesth. 2007;19(1):3-8.

103. Zoremba M, Dette F, Hunecke T, Eberhart L, Braunecker S, Wulf H. A comparison of desflurane versus propofol: the effects on early postoperative lung function in overweight patients. Anesth Analg. 2011;113(1):63-9.

104. Arain SR, Barth CD, Shankar H, Ebert TJ. Choice of volatile anesthetic for the morbidly obese patient: sevoflurane or desflurane. J Clin Anesth. 2005;17(6): 413-9.

105. Al-Hashimi M, Scott SW, Thompson JP, Lambert DG. Opioids and immune modulation: more questions than answers. Br J Anaesth. 2013;111(1):80-8.

106. Nishina K, Akamatsu H, Mikawa K, Shiga M, Maekawa N, Obara H, Niwa Y. The inhibitory effects of thiopental, midazolam, and ketamine on human neutrophil functions. Anesth Analg. 1998;86(1):159-65.

107. Vuyk J, Sitsen E, Reekers M. Intravenous anesthetics. In: Miller RD, editor. Miller's anesthesia, vol. 1. 8a ed. Philadelphia: Elsevier Saunders; 2015. p. 838.

108. Brill MJ, van Rongen A, Houwink AP, Burggraaf J, van Ramshorst B, Wiezer $\mathrm{RJ}$, van Dongen EP, Knibbe CA. Midazolam pharmacokinetics in morbidly obese patients following semi-simultaneous oral and intravenous administration: a comparison with healthy volunteers. Clin Pharmacokinet 2014;53(10):931-41.

109. Freid EB. The rapid sequence induction revisited: obesity and sleep apnea syndrome. Anesthesiol Clin North Am. 2005;23(3):551-64 viii.

110. Mulier JP, Dillemans B. Anaesthetic factors affecting outcome after bariatric surgery, a retrospective levelled regression analysis. Obes Surg. 2019;29(6): 1841-50.

111. Frauenknecht J, Kirkham KR, Jacot-Guillarmod A, Albrecht E. Analgesic impact of intra-operative opioids vs. opioid-free anaesthesia: a systematic review and meta-analysis. Anaesthesia. 2019;74(5):651-62.

112. Inoue T, Tanaka S, Okusa MD. Neuroimmune interactions in inflammation and acute kidney injury. Front Immunol. 2017;8:945.

113. Lontchi-Yimagou E, Sobngwi E, Matsha TE, Kengne AP. Diabetes mellitus and inflammation. Curr Diab Rep. 2013;13(3):435-44.

114. Pascual-Figal DA, Bayes-Genis A, Asensio-Lopez MC, Hernández-Vicente A, Garrido-Bravo I, Pastor-Perez F, Díez J, Ibáñez B, Lax A. The interleukin-1 axis and risk of death in patients with acutely decompensated heart failure. J Am Coll Cardiol. 2019;73(9):1016-25.

115. Nishida K, Otsu K. Inflammation and metabolic cardiomyopathy. Cardiovasc Res. 2017;113(4):389-98.

Ready to submit your research? Choose BMC and benefit from:

- fast, convenient online submission

- thorough peer review by experienced researchers in your field

- rapid publication on acceptance

- support for research data, including large and complex data types

- gold Open Access which fosters wider collaboration and increased citations

- maximum visibility for your research: over $100 \mathrm{M}$ website views per year

At BMC, research is always in progress.

Learn more biomedcentral.com/submissions 